\title{
PERGAMON
}

www.elsevier.com/locate/watres

\section{OBSERVATIONS ON CHANGES IN ULTRASONICALLY TREATED WASTE-ACTIVATED SLUDGE}

\author{
C. P. CHU ${ }^{1}$, BEA-VEN CHANG ${ }^{2}$, G. S. LIAO ${ }^{2}$, D. S. JEAN ${ }^{1}$ and D. J. LEE*1 \\ ${ }^{1}$ Chemical Engineering Department, National Taiwan University, Taipei, 106 Taiwan and ${ }^{2}$ Department \\ of Microbiology, Soochow University, Taipei, 111 Taiwan
}

(First received 6 December 1999; accepted in revised form 18 June 2000)

\begin{abstract}
This work experimentally elucidates the effects of ultrasonic treatment on the physical, chemical, and biological characteristics of a waste-activated sludge. A critical ultrasonic power level exists above which, accompanied with the release of divalent cations from the sludge body, the floc structure effectively disintegrated, microbial level acceptably disinfected, and particulate organic compounds sufficiently transformed into soluble state. Both ultrasonic vibration and bulk temperature rise contribute to the treatment efficiency. Possible mechanisms of ultrasonic treatment are discussed. (C) 2001 Elsevier Science Ltd. All rights reserved.
\end{abstract}

Key words - ultrasound, sludge, pretreatment, microbial density, dewaterability, biodegradability

\section{INTRODUCTION}

The biodegradability of waste sludge can be improved by using thermal energy (Stuckey and McCarty, 1984; Li and Noike, 1992; Baier, 1997), enzymes (Knapp and Howell, 1978), ozonation (Yasui and Shibata, 1994), acidification (Gaudy et al., 1971; Woodard and Wukasch, 1994), alkaline addition (Mukherjee and Levine, 1992; Lin et al., 1989; Haug et al., 1978), high pressure (Dollerer and Wilderer, 1993), mechanical disintegration (Baier and Schmidheiny, 1997; Kopp et al., 1997) and ultrasound (Muller and Schwedes, 1996; Tiehm et al., 1997). Some investigations discussed the combined treatment of alkaline addition and ultrasound (Stuckey and McCarty, 1978; Kenzevic et al., 1994; Chiu et al., 1997a,b). Among these processes the employment of physical treatments, like ultrasound, exhibits the benefit of not being hazardous to the environment (Bien and Wolny, 1997).

Ultrasound is a pressure wave that propagates through a medium with a vast amount of energy dissipation. Gas and vapor bubbles would generate, grow, and collapse violently at high velocity (termed “acoustic cavitation") (Neppiras, 1980). Strong turbulent eddies of size 5-100 $\mu \mathrm{m}$ are induced around the collapsing bubbles. High temperature and pressure developed inside the collapsing bubbles could induce many physico-chemical effects (Monnier

*Author to whom all correspondence should be addressed. Fax: 886-2-2362-3040; e-mail: djlee@ccms.ntu.edu.tw et al., 1999). Cavitation occurs more readily at a frequency of $20-40 \mathrm{kHz}$ (Atchley and Crum, 1988).

The use of ultrasound to "condition" sludge is not a new approach. Due to the micro-scale bubble explosions caused by ultrasonic waves, researchers employed this technique for counting the number of bacterial cells (Banks and Walker, 1977; Hughes and Stafford, 1976; Williams et al., 1970, 1971), extracting the exocellar polymer (Brown and Lester, 1980; Kiff and Thompson, 1979; King and Forster, 1990) and investigating the surface properties of microorganisms in sludge (Urban et al., 1993; Jorand et al., 1994). In the first stage of sonication the structure of sludge flocs would be effectively disintegrated (Tiehm et al., 1997). In the subsequent stage, some portion of the insoluble particulate organic matter could be transformed into a soluble state (Tatsuo et al., 1993; Jorand et al., 1995; Chiu et al., 1997a). Meanwhile, the excess power input could yield a marked temperature rise after a long-duration operation. The heating effects are unavoidably accompanied and cannot be ignored (Chiu et al., 1997b).

The hygienic properties of sludge and organic waste are of essential importance in sludge handling and disposal (Chu et al., 1999). A few studies elucidated the effects of pretreatment on the pathogenic microorganisms (Allevi et al., 1994; Bossart and McCreary, 1983; Pancorbo et al., 1988; Schuh et al., 1985; Jepsen et al., 1997). Information regarding the microbial density levels after ultrasonic treatment is still largely lacking (Prasad et al., 1993; Qian et al., 1997). To employ ultrasound as a sludge conditioner in field one would be interested in the 
changes in physical, chemical, and biological aspects of a sludge. This work primarily focuses upon the effects of ultrasonic treatment on the physical (floc size, filterability, settleability, bound water content, and surface charge), chemical (chemical oxygen demand, biochemical oxygen demand, and concentrations of divalent cations in supernatant), and biological (survival ratios of heterotrophic bacteria and of total coliform) characteristics of a wasteactivated sludge. The effects of both power level and sonication time were investigated. The mechanism of ultrasonic treatment on sludge characteristics is also discussed.

\section{EXPERIMENTAL}

\section{Sample}

The waste-activated sludge was taken from a wastewater treatment plant in Presidential Enterprise Co., Taoyuan, Taiwan. The main product of this plant included bread and cake. The wastewater mainly came from the food-processing units, at a flow rate of $250 \mathrm{t}$ daily. The oil and grease in the influent was first removed. Then the wastewater entered the primary and secondary treatment units. The biological sludge was concentrated in the secondary clarifier, partially recycled back to the aeration basin. The sampling point was at the reflux stream of the activated sludge.

All tests started within $2 \mathrm{~h}$ after sampling to prevent subsequent sludge changes. The total solid content was measured as $8240 \mathrm{mg} / \mathrm{l}$. Accupyc Pycnometer 1330 (Micromeritics) measured the true density of dried solid in sludge, giving a result of $1453 \mathrm{~kg} / \mathrm{m}^{3}$ with a relative deviation of less than $0.5 \%$. The $\mathrm{pH}$ value of the original sludge was approximately 7.0. The microscopic pictures of sludge flocs were obtained with a phase contrast microscope (ECLIPSE E800, Nikon) at a magnification of $1000 \times$. Figure 1 depicts the microphotograph of the original sludge flocs. A highly porous structure and the presence of filamentous bacteria were noted.

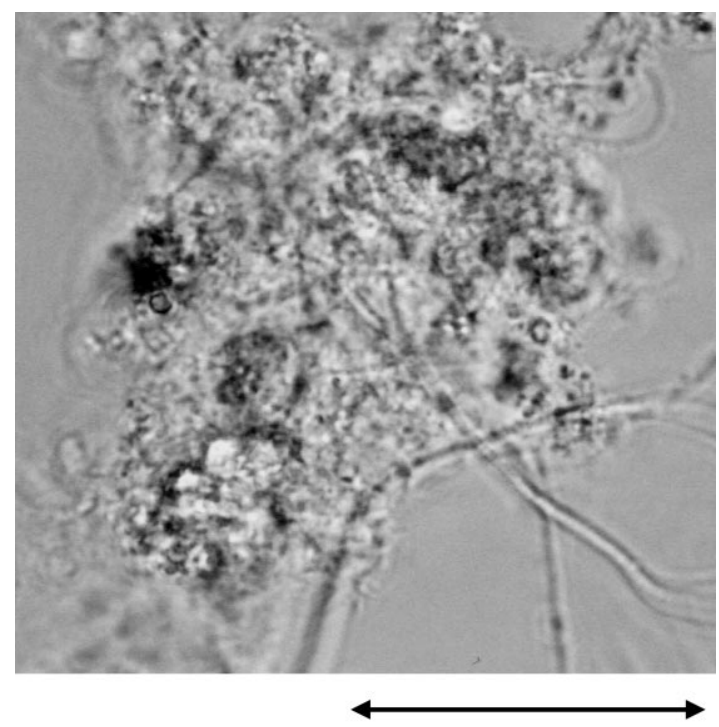

$50 \mu \mathrm{m}$

Fig. 1. Microscopic photograph of original sludge $1000 \times$.

\section{Ultrasonic treatment}

Sonication tests were conducted with the help of a cellbreaker (SONICATOR XL-2020, Heat system-Ultrasonics, Inc.). The frequency was $20 \mathrm{kHz}$ and the maximum power input was $110 \mathrm{~W}$. Effects of sonication depend largely upon the sample volume, container geometry, and the probe position. $250 \mathrm{ml}$ waste-activated sludge was placed in a $500 \mathrm{ml}$ beaker with the probe allocated at $2 \mathrm{~cm}$ above the beaker bottom. The sonication time was in the range 20 $120 \mathrm{~min}$. The temperature of the sludge would markedly increase after sonication. For example, after $120 \mathrm{~min}$ sonication at $110 \mathrm{~W}(0.44 \mathrm{~W} / \mathrm{ml})$, the sludge which was originally at $4^{\circ} \mathrm{C}$ would increase to higher than $60^{\circ} \mathrm{C}$. The temperature effect is discussed at the end of this paper.

\section{Physical characteristics}

$\zeta$ potentials of the sludge flocs were measured by a zeta meter (Zeta-Meter System, 3.0, Zeter-Meter Inc., USA). A particle sizer (Coulter LS230) estimated the average floc diameters $\left(d_{\mathrm{f}}\right)$. Capillary suction apparatus was employed to estimate the sludge filterability. The inner cylinder radius was $0.535 \mathrm{~cm}$ and Whatman No. 17 paper was the filter paper. The time for filtrate to invade from 1.5 to $3.0 \mathrm{~cm}$ is referred to as capillary suction time (CST). Hindered settling tests were performed in tubes of diameter $1 \mathrm{~cm}$ and height $15 \mathrm{~cm}$, from which the zone settling velocity data could be extracted. The ratio between the final and initial sediment heights $\left(l_{\mathrm{f}} / l_{\mathrm{i}}\right)$ was reported after $24 \mathrm{~h}$ settling. (Note: A strong wall effect exists for settling tests in the present $1 \mathrm{~cm}$ diameter settling tube. Nevertheless, the wall effect would be largely cancelled out if only the difference between the settling velocities among samples is considered; Chen et al., 1996). A constant head piston press (Triton Electronics Ltd., type 147) was employed for expression tests. The testing sludge was placed in the inner stainlesssteel cylinder of diameter $7.62 \mathrm{~cm}$ and of height $20 \mathrm{~cm}$ covered with a movable piston. A hydraulic pressure of $2.07 \times 10^{7} \mathrm{~Pa}(3000 \mathrm{psi})$ was then exerted onto the piston to force the moisture out from the bottom drainage surface. The moisture remained in the sludge cake at the end of the high-pressure consolidation was defined as the bound water of the sludge ( $\left.W_{\mathrm{W}, \mathrm{EXP}}\right)$ (Lee, 1994; Lee and Hsu, 1995).

\section{Chemical characteristics}

The biochemical oxygen demand (BOD), and the total chemical oxygen demand (TCOD) of sludge and the soluble chemical oxygen demand (SCOD) in supernatant were measured with BOD meter $(2173 \mathrm{~B}, \mathrm{HACH}, \mathrm{USA})$ and spectrophotometer (DR/2000, HACH, USA), respectively. (Note: The TCOD value was measured for the entire sludge body sampled after being completely mixed. The SCOD value was measured for the supernatant only). TCOD, SCOD and BOD of the original sludge were $5420 \mathrm{mg} / 1$, $42 \mathrm{mg} / \mathrm{l}$, and $3555 \mathrm{mg} / \mathrm{l}$, respectively. An ICP Mass Spectrometer (ELAN 6000, Perkin Elmer) measured the ionic concentrations in the supernatant of sludge. Some sludge samples were washed by reverse-osmosis water for more than 5 times to remove most ions in the supernatant prior to ultrasonic treatment. After washing, the ionic concentrations are reduced to lower than $1 \mathrm{mg} / 1$. The ionic concentration had not increased to a detectable extent for $2 \mathrm{~h}$ washing, denoting a negligible role of osmotic pressure to dissolve solute from the cells. Comparing the results for sludge before and after sonication reveals the amounts of ions released from the sludge body owing to ultrasonication.

\section{Microbial enumerations}

Heterotrophic bacteria were enumerated by using heterotrophic plate count (HPC) and R2A agar. A dilution series $\left(10^{-3}-10^{-5}\right)$ of each sample was prepared by serially 
transferring a $1 \mathrm{ml}$ portion of sludge. Plates were incubated at $35^{\circ} \mathrm{C}$ for 5 days (APHA, 1992). Total coliform were enumerated by using a five-tube Most Probable Number (MPN). We used lauryl tryptose broth in the presumptive and confirmed phase of multiple tube test (APHA, 1992). All media ingredients were purchased from Difco Laboratories (Detroit, Mich.). The microbial density levels were measured as $5.1 \times 10^{7}$ colony-forming units $(\mathrm{CFU}) / \mathrm{ml}$ for heterotrophic bacteria and $4.9 \times 10^{5} \mathrm{MPN} / \mathrm{ml}$ for the total coliform, respectively.

\section{RESULTS AND DISCUSSION}

\section{Structural changes}

Figure 2 depicts the floc size after ultrasonic vibration at various power levels and duration times. The original sludge floc exhibits a mean diameter of $98.9 \mu \mathrm{m}$. The tests at $0.11 \mathrm{~W} / \mathrm{ml}$ have almost no effects on the floc size. Only when the power level has exceeded $0.22 \mathrm{~W} / \mathrm{ml}$ would the particle size apparently decrease. As Fig. 2 reveals, at $0.33 \mathrm{~W} / \mathrm{ml}$, the floc diameter reduces to $22 \mu \mathrm{m}$ after $20 \mathrm{~min}$ or to approximately $4 \mu \mathrm{m}$ after $120 \mathrm{~min}$ sonication. At $0.44 \mathrm{~W} / \mathrm{ml}$, the floc size drops to less than $3 \mu \mathrm{m}$ in $20 \mathrm{~min}$. Further sonication would only mildly reduce the floc size further.

Figure 3 demonstrates the microphotographs $(1000 \times)$ for flocs after sonication for $40 \mathrm{~min}$ at $0.11 \mathrm{~W} / \mathrm{ml}$. Although the floc structure becomes somewhat looser and some filamentous bacteria have been exposed outside, the architecture of floc is basically the same as the original sludge.

Figure 4(a)-(e) demonstrate the microphotographs $(1000 \times)$ for flocs after sonication at $0.33 \mathrm{~W} / \mathrm{ml}$ up to $2 \mathrm{~h}$. The structural integrity of flocs has almost completely broken down after $40 \mathrm{~min}$ sonication. A critical power level thereby exists beyond which the sludge flocs could be sufficiently disintegrated. Wen and Lee (1998) discussed the floc's interior binding

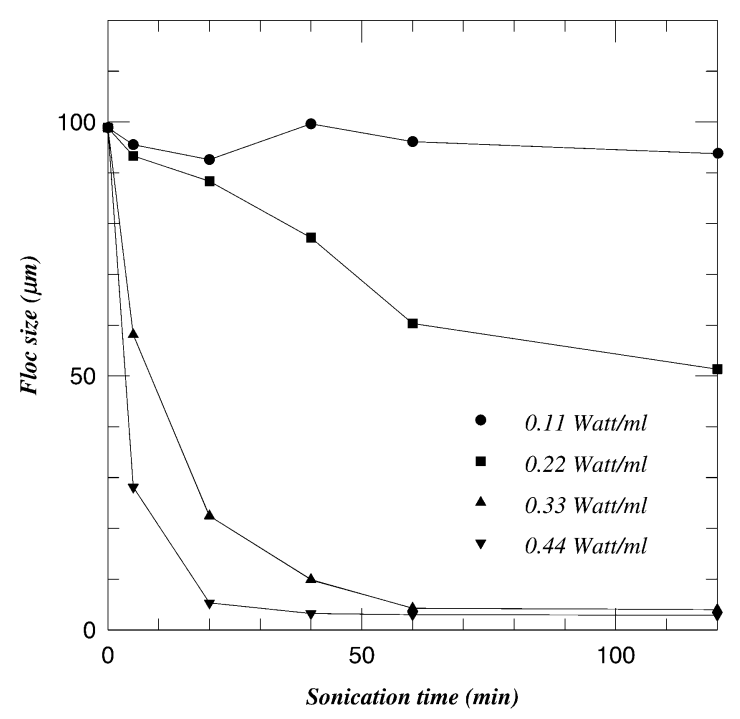

Fig. 2. Floc size vs. sonication time.

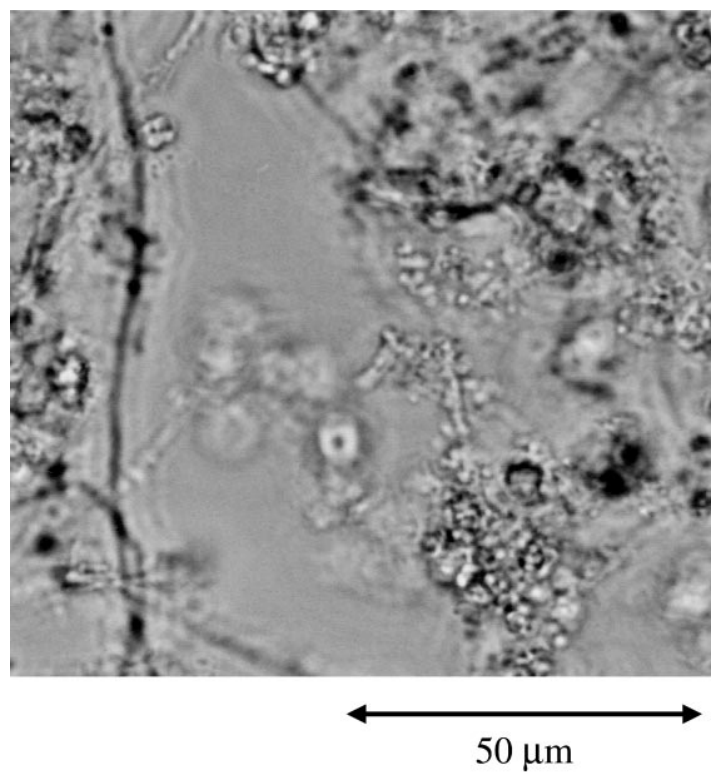

Fig. 3. Microscopic photograph of ultrasound treated sludge for $40 \mathrm{~min}$ at $0.11 \mathrm{~W} / \mathrm{ml}, 1000 \times$.

strength and its implications to floc size after ultrasonication.

Table 1 also lists the $\zeta$ potential of colloidal particles and the concentrations of $\mathrm{Ca}^{2+}$ and $\mathrm{Mg}^{2+}$ ions in the supernatant. Apparently, ultrasonic treatment has no effects on the surface charges of the suspended particles. However, as floc breakage occurs, the concentrations of $\mathrm{Ca}^{2+}$ and $\mathrm{Mg}^{2+}$ ions in the supernatant markedly increase. The calcium and magnesium ions are generally accepted as the essential components to bridge the constituent particles in a sludge floc (Bruus et al., 1992; Urban et al., 1993; Sanin and Vesilind, 1996; Chang et al., 1997; Higgins and Novak, 1997a, b; Cousin and Ganczarczyk, 1998; Novak et al., 1998). At a level of $0.33 \mathrm{~W} / \mathrm{ml}$, however, the release of the $\mathrm{Ca}^{2+}$ and $\mathrm{Mg}^{2+}$ ions was noted during 20-40 min of ultrasonication prior to major floc structure deterioration. In other words, although divalent ions could play on essential role in the integrity of sludge flocs (Jean and Lee, 1999), the breakdown of global sludge floc is not necessarily directly associated with the release of these divalent cations.

\section{Dewaterability}

Table 1 lists the CST and $W_{\mathrm{W} \text {,EXP }}$ data. The ZSV values for all sludge samples, regardless of the employment of ultrasonic treatment, are essentially zero. In addition, the ratio $l_{\mathrm{f}} / l_{\mathrm{i}}$ is very close to unity. In other words, the settleability of sludge is not enhanced by ultrasonic treatment. These data are therefore not included in Table 1 .

According to the CST data, sonication at $0.11 \mathrm{~W} /$ $\mathrm{ml}$ only slightly deteriorates the sludge's filterability (from 197s for the original sludge to $218 \mathrm{~s}$ after 

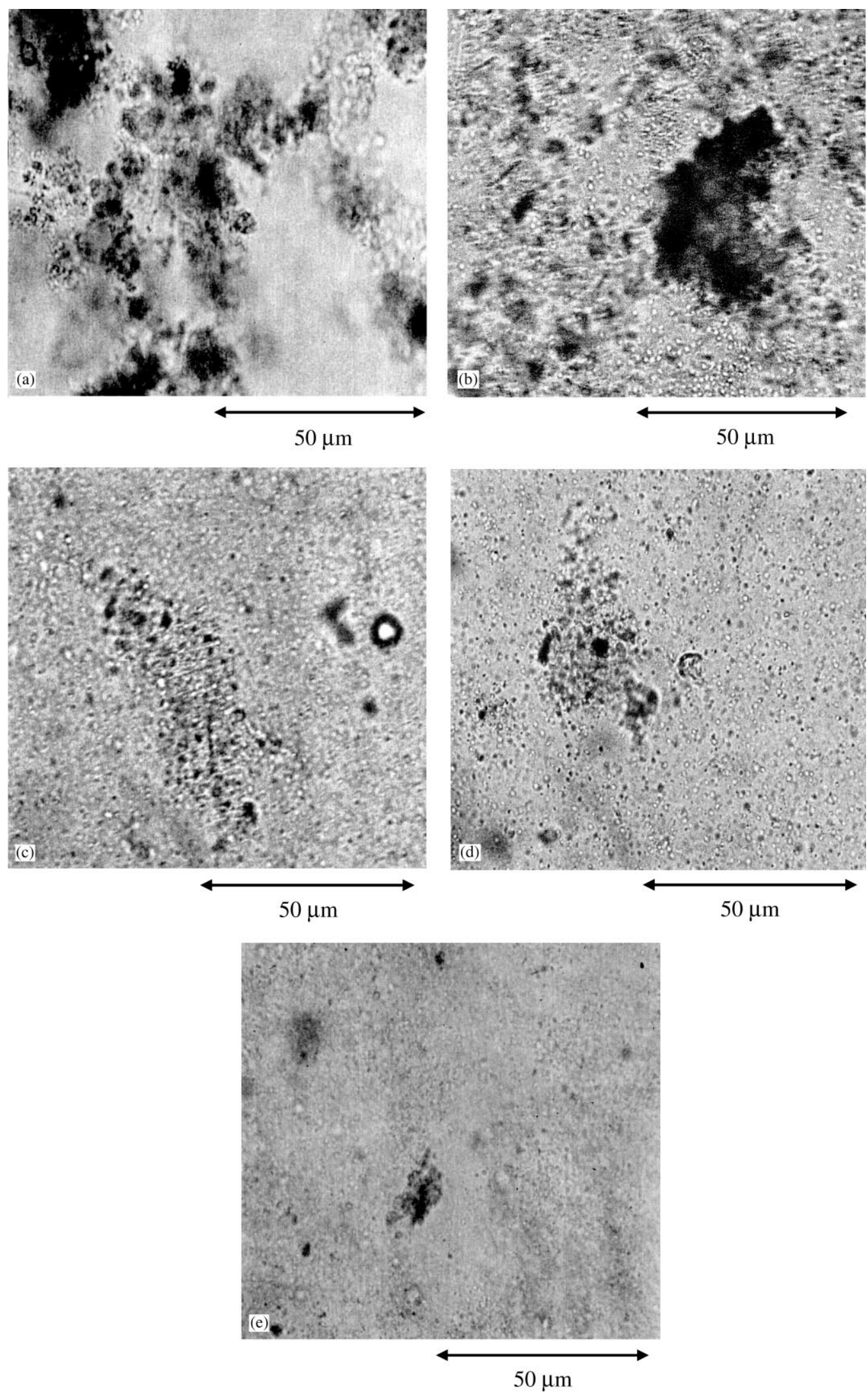

Fig. 4. Microscopic photograph of ultrasound treated sludge at $0.33 \mathrm{~W} / \mathrm{ml}, 1000 \times$ : (a) $5 \mathrm{~min}$; (b) $20 \mathrm{~min}$; (c) $40 \mathrm{~min}$; (d) $60 \mathrm{~min}$; (e) $120 \mathrm{~min}$. 
Table 1. Sludge characteristics after ultrasonic vibration

\begin{tabular}{|c|c|c|c|c|c|}
\hline & $\zeta$ potential $(\mathrm{mV})$ & $\mathrm{Ca}^{2+}(\mathrm{ppm})$ & $\mathrm{Mg}^{2+}(\mathrm{ppm})$ & CST (sec) & $W_{\mathrm{W}, \mathrm{EXP}}(\mathrm{kg} / \mathrm{kg} \mathrm{DS})$ \\
\hline Original & -16.4 & 1.9 & 1.1 & 197.4 & 3.78 \\
\hline $0.11 \mathrm{~W} / \mathrm{ml} 20 \mathrm{~min}$ & -15.9 & 2.9 & 1.4 & 188.2 & 4.16 \\
\hline $0.11 \mathrm{~W} / \mathrm{ml} 40 \mathrm{~min}$ & -15.8 & 3.4 & 1.9 & 204.9 & 4.81 \\
\hline $0.11 \mathrm{~W} / \mathrm{ml} 60 \mathrm{~min}$ & -16.7 & 3.8 & 2.2 & 218.4 & 5.90 \\
\hline $0.33 \mathrm{~W} / \mathrm{ml} 20 \mathrm{~min}$ & -17.1 & 4.0 & 2.8 & 304.6 & 7.14 \\
\hline $0.33 \mathrm{~W} / \mathrm{ml} 40 \mathrm{~min}$ & -17.5 & 10.3 & 4.3 & 405.6 & 9.78 \\
\hline $0.33 \mathrm{~W} / \mathrm{ml} 60 \mathrm{~min}$ & -17.0 & 18.2 & 9.7 & 488.9 & 11.67 \\
\hline
\end{tabular}

60 min treatment). However, the CST for $0.33 \mathrm{~W} / \mathrm{ml}$ treated sludge had been significantly increased. For example, after $60 \mathrm{~min}$ sonication the CST increases up to $490 \mathrm{~s}$. The bound water content $\left(W_{\mathrm{W}, \mathrm{EXP}}\right)$ for the original sludge is $3.8 \mathrm{~kg} / \mathrm{kg}$ DS. At a power level of $0.11 \mathrm{~W} / \mathrm{ml}$ the value of $W_{\mathrm{W} \text {,EXP }}$ increases to $5.9 \mathrm{~kg} /$ $\mathrm{kg}$ after $60 \mathrm{~min}$ sonication. At a level of $0.33 \mathrm{~W} / \mathrm{ml}$, on the other hand, $W_{\mathrm{W}, \mathrm{EXP}}$ becomes $11.7 \mathrm{~kg} / \mathrm{kg}$, approximately at a four-fold increase. Therefore, the dewaterability of sludge has been seriously deteriorated after ultrasonic treatment. Such an observation is attributed to the fact that a great amount of water could be attached onto the large surfaces provided by the small particles after ultrasonication.

\section{Microbial density level}

Figure 5 represents the survival ratios of heterotrophic bacteria and of total coliform against the sonication time, with power level as a parameter. Herein, the survival ratio, $S$, is defined as the ratio of the viable bacteria density levels after treatment to those of the original sludge.

At $0.11 \mathrm{~W} / \mathrm{ml}$, the heterotrophic bacteria density starts to markedly decrease after $60 \mathrm{~min}$ of sonication. Jorand et al. (1995) also noted that cell lysis would occur only after a period of sonication. At

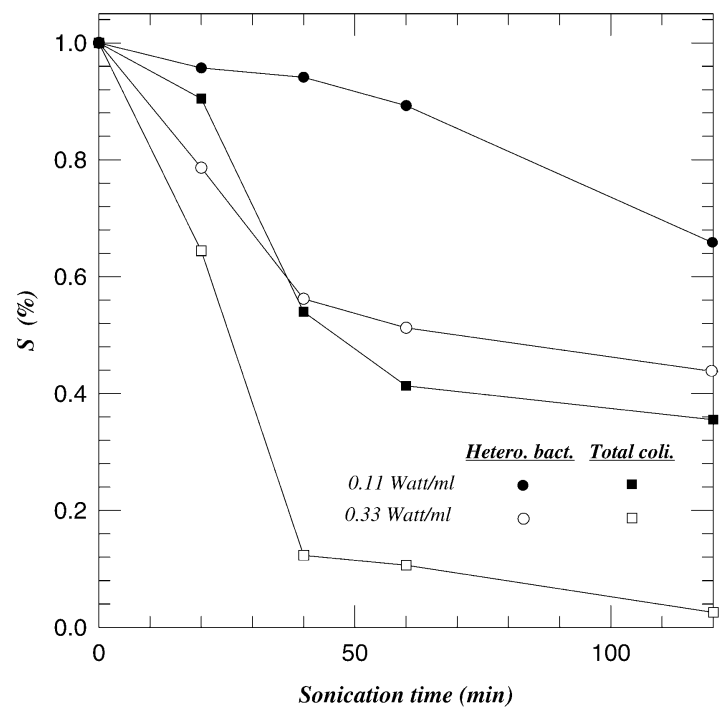

Fig. 5. Survival ratio $(S)$ vs. sonication time.
120 min treatment, $S$ reduces to $66 \%$ of that of the original sludge, indicating a $34 \%$ reduction. As compared with the heterotrophic bacteria density level, the total coliform is much easier to be disinfected. For example, at $60 \mathrm{~min}$ sonication $S$ has reached a level of $41 \%$. At $120 \mathrm{~min}$ sonication, the density level of total coliform is reduced by $64 \%$, that is, $S=36 \%$. In other words, even though neither the floc size nor the dewaterability of sludge had been markedly affected, the microbial density levels still could be reduced after a long time of sonication.

As Fig. 5 reveals, as expected, the $S$ ratios at $0.33 \mathrm{~W} / \mathrm{ml}$ of heterotrophic bacteria and of total coliform are less than those at $0.11 \mathrm{~W} / \mathrm{ml}$. The $S$ value decreases with sonication time, and reaches a value of $44 \%$ for heterotrophic bacteria and 3\% for total coliform, respectively, at $120 \mathrm{~min}$. Heterotrophic bacteria still more readily resist ultrasonic treatment than does the total coliform.

\section{Release of organic compounds}

Figure 6 depicts the changes in SCOD/TCOD and BOD/TCOD ratios after ultrasonic treatment. For the original sludge, although approximately $66 \%$ of the total COD is biodegradable (BOD/ TCOD $=0.66$ ), most $\mathrm{COD}$ is associated with the

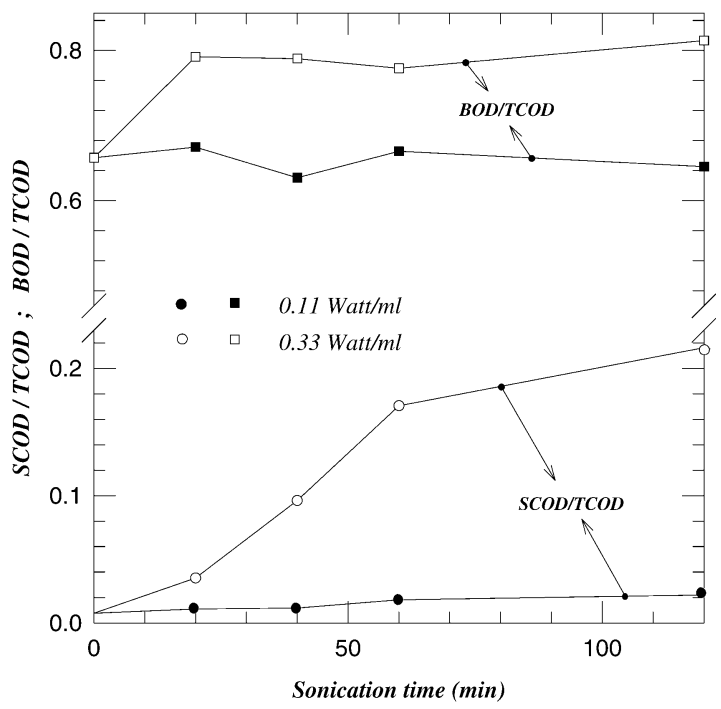

Fig. 6. SCOD/TCOD and BOD/TCOD vs. sonication time. 
solid phase rather than in a soluble form, as evidenced by the rather low SCOD/TCOD ratio at zero sonication time $(0.5 \%)$. At a low power level of $0.11 \mathrm{~W} / \mathrm{ml}$, SCOD has not significantly changed, only increasing slightly to approximately $2 \%$ after $120 \mathrm{~min}$ sonication. Furthermore, the BOD/TCOD ratio is kept almost unchanged as well.

At $0.33 \mathrm{~W} / \mathrm{ml}$, on the other hand, about $20 \%$ of the total COD has been transformed into supernatant after $120 \mathrm{~min}$ sonication. The COD in supernatant thereby has increased by 40 times after ultrasonic treatment. Such an observation closely corresponds to that in Tiehm et al. (1997). In addition, the BOD/ TCOD ratio increases from $66 \%$ to around $80 \%$, indicating that most of the released $\mathrm{COD}$ is biodegradable. Ultrasonic treatment thereby can markedly enhance the sludge biodegradability (Tiehm et al., 1997). However, with data scattering, such an observation correlates closely with the trends in microbial density reduction as depicted in Fig. 4. Consequently, the release of COD from sludge body may be the consequence of the decay of microorganisms in the sludge body. (Note: Since the heterotrophic bacteria are in excess number compared to that for total coliform bacteria, the correspondence actually depends upon the former rather than the latter). In some tests, like $0.11 \mathrm{~W} / \mathrm{ml}$ for $20 \mathrm{~min}$ the inactivation of microorganisms was noted prior to the occurrence of increase in COD. This might simply reveal that although microorganisms had been disinfected during ultrasonication, cell lysis had not occurred except when further energy was supplied.

\section{Temperature effects}

Two effects occur simultaneously in ultrasonic treatment: vigorous agitation caused by tiny bubble formation and explosion, and the increase in the bulk temperature. Figure 7 illustrates the temperature changes after ultrasonication at various power levels. Notably, the bath temperature increases rapidly with the application of ultrasound. At $0.44 \mathrm{~W} / \mathrm{ml}$, the batch temperature increases exceeding $50^{\circ} \mathrm{C}$ within $2 \mathrm{~min}$. To isolate the sonication effect from the possible interference of bulk temperature, in some tests the beakers were immersed in an iced pool to maintain the bulk temperature at approximately $15^{\circ} \mathrm{C}$. After ultrasonic treatment the sludge samples were stored at $4{ }^{\circ} \mathrm{C}$ for $6 \mathrm{~h}$ prior to subsequent tests. The storage and testing procedures were the same as those discussed above.

Figure 8 demonstrates the SCOD/TCOD ratio with temperature control, in which the results without temperature control are also depicted for the sake of comparison. The SCOD/TCOD ratio would be lower for the former (at $15^{\circ} \mathrm{C}$ ) than for the latter. For example, at $0.11 \mathrm{~W} / \mathrm{ml}$, sonication to $15^{\circ} \mathrm{C}$ sludge could release almost no COD from the solid state to the soluble state. Without temperature control, the bulk solution gradually rises in temperature with

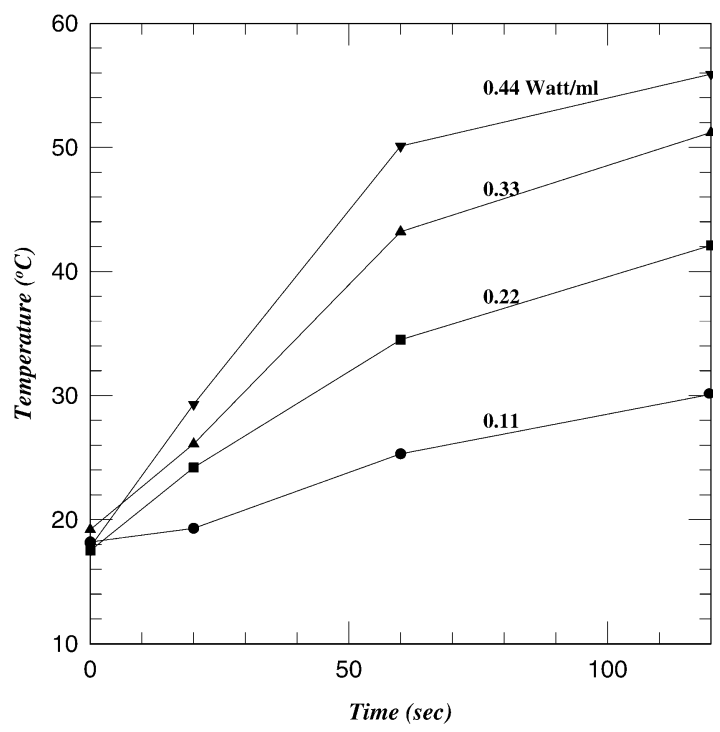

Fig. 7. Temperature variations with time at various power levels.

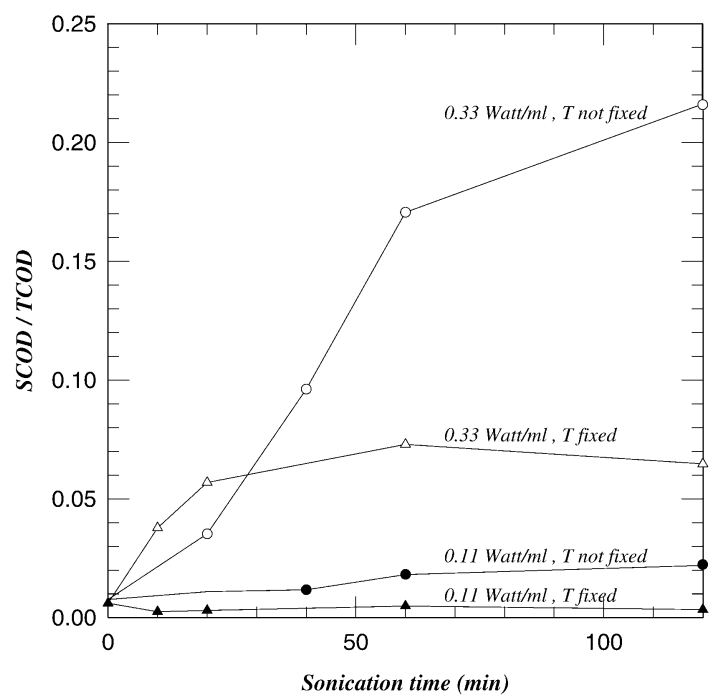

Fig. 8. SCOD/TCOD ratios vs. sonication time with and without bulk temperature control.

approximately $2 \%$ of COD having been successfully released. The difference at $0.33 \mathrm{~W} / \mathrm{ml}$ becomes more pronounced. With temperature control the SCOD/ TCOD soon reaches a plateau value of approximately $7 \%$, indicating an ultimate capability of ultrasound on organic transformation. On the other hand, the COD is continuously released to supernatant up to $120 \mathrm{~min}$ when the bulk temperature rises up to $60^{\circ} \mathrm{C}$.

For demonstrating the possible temperature effects, some sludge samples were heated up and maintained for $1 \mathrm{~h}$ at a fixed temperature ranging from 25 to $55^{\circ} \mathrm{C}$ (without sonication). Table 2 lists the floc size, microbial density levels, and SCOD/ TCOD ratios of treated sludge, where $d_{\mathrm{f} 0}$ denotes the 
Table 2. Sludge characteristics after 1-h heating

\begin{tabular}{|c|c|c|c|c|}
\hline Temperature $\left({ }^{\circ} \mathrm{C}\right)$ & $d_{\mathrm{f}} / d_{\mathrm{f} 0}^{\mathrm{a}}(\mu \mathrm{m})$ & $S_{\mathrm{HB}}$ & $S_{\text {Coliform }}$ & $\mathrm{SCOD} / \mathrm{COD}$ \\
\hline 25 & 0.997 & 1.00 & 1.00 & 0.008 \\
\hline 35 & 0.986 & 0.86 & 0.99 & 0.037 \\
\hline 45 & 0.984 & 0.60 & 0.47 & 0.094 \\
\hline 55 & 0.966 & 0.48 & 0.27 & 0.165 \\
\hline
\end{tabular}

${ }^{\mathrm{a}} d_{\mathrm{f} 0}$ denotes the floc size of the original sludge. The density level of heterotrophic bacteria in the original sludge was $5.1 \times 10^{7} \mathrm{CFU} / \mathrm{ml}$, and that of the total coliform, $4.9 \times 10^{5} \mathrm{MPN} / \mathrm{ml}$.

floc size of the original sludge, $98.9 \mu \mathrm{m}$. Apparently, heating alone could not significantly deteriorate the floc structure. The floc diameter is kept almost unchanged up to $55^{\circ} \mathrm{C}$. On the other hand, both heterotrophic bacteria and total coliform are largely disinfected at higher temperatures, accompanied with an increase in the SCOD values. Comparison with the sonication test in Figs. 5, 6 and 8 at 60 min reveals that both bubble explosion and the induced bulk solution temperature rise are equally important in sludge floc disintegration and cell lysis.

\section{Ultrasonic treatment on sludge flocs}

The above-mentioned observation thereby reveals that the ultrasonic treatment is a multi-stage process. Activated sludge flocs are a multi-level object (a multifractal) (Lee, 1999). The formation model of floc by Gorczyca and Ganczarczyk (1998) consists of the primary particles $(\approx 2 \mu \mathrm{m})$, the compact flocculi and microflocs $(\approx 13 \mu \mathrm{m})$, and highly porous flocs $(\approx 100 \mu \mathrm{m})$. The mechanical force generated by ultrasonic waves at $0.44 \mathrm{~W} / \mathrm{ml}$ could disintegrate the highly porous floc into microflocs or flocculi and release some extracellular polymer (Jorand et al., 1995).

At the first stage of sonication $(0-20 \mathrm{~min})$ at a power input exceeding the critical level the mechanical forces (and the associated high-temperature micro-environment) induced by collapsing bubbles break down the floc structure (Fig. 2). For example, at $0.44 \mathrm{~W} / \mathrm{ml}$ power level, the floc size decreases to a pseudo-plateau regime of size near compact flocculi $(\approx 5 \mu \mathrm{m})$ after $20 \mathrm{~min}$ of sonication (Fig. 2). At $0.22 \mathrm{~W} / \mathrm{ml}$, however, it is also clear that the disintegration of sludge flocs is not complete. The overall structure is still partially sustained $(\approx 50 \mu \mathrm{m})$ after sonication (Fig. 2). Small particles were not favorable for the filtration and settling (Vesilind et al., 1991; Lee, 1997). The deterioration of sludge dewaterability correlates well with the decrease in sludge floc size (Table 1).

In the subsequent stage $(20-60 \mathrm{~min})$, both heterotrophic bacteria and total coliform are effectively disinfected at $0.33 \mathrm{~W} / \mathrm{ml}$ (Fig. 5). However, test at $0.11 \mathrm{~W} / \mathrm{ml}$ cannot effectively inactivate the heterotrophic bacteria. In microscopic view, the temperature increase (or heating) in the micro-bubbles would generate many free radicals (Monnier et al., 1999) that should contribute largely to microbial inactiva- tion and organic dissolution. The SCOD value increases accompanied with the reduction in the microbial density levels (Fig. 6).

In the final stage $(60-120 \mathrm{~min})$, if the bulk temperature has been controlled, ultrasonic treatment has essentially no effects on the sludge characteristics. If the bulk temperature of sludge were not controlled, even the treatment at $0.11 \mathrm{~W} / \mathrm{ml}$ could effectively disinfect the total coliform as time exceeds $60 \mathrm{~min}$, which might be attributed to the rise in bulk temperature. Similar results are also noted for the tests at elevated temperatures for $1 \mathrm{~h}$ (Table 2). Therefore, the bulk temperature is an essential factor that controls the subsequent transformation of solidstate organic compounds.

The density level for treated sludge at $0.33 \mathrm{~W} / \mathrm{ml}$ for more than $60 \mathrm{~min}$ can be lower than $6.3 \times 10^{6} \mathrm{MPN} / \mathrm{g}$ dried solid (DS) for the total coliform. A sludge could be taken as Class B sludge according to US Sludge Regulations if its fecal coliform is at a level less than $2 \times 10^{6} \mathrm{MPN} / \mathrm{g}$ DS. We had not measured the fecal coliform concentration in this work. However, since the fecal coliform in a wastewater stream is usually observed to exist at a level an order of magnitude less than the total coliform, the present sludge treated at an optimal condition has a chance to be taken as a Class B sludge.

\section{CONCLUSIONS}

This work experimentally elucidates the effects of ultrasonic treatment on the physical, chemical, and biological characteristics of a waste-activated sludge. A critical ultrasonic power level exists above which the floc structure can be effectively disintegrated. The ultrasonic treatment consists of several stages. At the first stage of sonication at a power input exceeding the critical level the porous floc can be readily deteriorated into compact flocculi, while the dewaterability of sludge is markedly deteriorated. In the second stage, although the floc size has remained almost unchanged, both heterotrophic bacteria and total coliform are effectively disinfected. The SCOD value increases accompanied with the reduction in the microbial density levels. In the final stage, if the bulk temperature has been controlled, ultrasonic treatment has essentially no effects on the sludge characteristics. However, the raised bulk temperature 
of sludge could induce continuous transformation of solid-state organic compounds into a soluble form. Since the density level of total coliform for treated sludge at the optimal condition can reach a rather low level, the present sludge has a potential to be taken as Class B sludge.

Acknowledgements - National Science Council, ROC, financially supported this work.

\section{REFERENCES}

Allievi L., Colombi A., Calcaterra E. and Ferrari A. (1994) Inactivation of fecal bacteria in sewage sludge by alkaline treatment. Bioresour. Technol. 49, 25-30.

APHA, American Public Health Association (1992) Standard Methods for the Examination of Water and Wastewater, 18th ed. American Public Health Association, Washington, DC, USA.

Atchley A. A. and Crum L. A. (1988) Acoustic cavitation and bubble dynamics. In Ultrasound-its Chemical, Physical, and Biological Effects, ed. K. S. Suslick, pp. 1-64. VCH Publishers, Weinheim.

Baier U. (1997) Thermal inactivation of plant seeds in sewage sludge. Water Sci. Technol. 36(11), 197-202.

Baier U. and Schmidheiny P. (1997) Enhanced anaerobic degradation of mechanically disintegrated sludge. Water Sci. Technol. 36(11), 137-143.

Banks C. J. and Walker I. (1977) Sonication of activated sludge flocs and the recovery of their bacteria on solid media. J. Gen. Microbiol. 98, 363-368.

Bien J. B. and Wolny L. (1997) Changes of some sewage sludge parameters prepared with an ultrasonic field. Water Sci. Technol. 36(11), 101-106.

Bossart J. M. and McCreary J. J. (1983) Disinfection. J. Water Pollut. Control Fed. 55, 650-657.

Brown M. J. and Lester J. N. (1980) Comparison of bacteria extracellar polymer extraction methods. Appl. Environ. Microbiol. 40, 179-185.

Bruus J. H., Nielsen P. H. and Keiding K. (1992) On the stability of activated sludge flocs with implications to dewatering. Water Res. 26, 1597-1604.

Chang M. C., Chuang S. H. and Lin H. L. (1997) Effects of calcium ion on sludge conditioning. Water Sci. Technol. 35(8), 217-222.

Chen G. W., Chang I. L., Hung W. T. and Lee D. J. (1996) Regimes of zone settling of waste activated sludge. Water Res. 30, 1844-1851.

Chiu Y. C., Chang C. N., Huang W. S. and Chao A. C. (1997a) Effect of ultrasonic and alkaline pretreatment on waste activated sludge characterization. J. Chin. I. Environ. Eng. 7, 25-33.

Chiu Y. C., Chang C. N., Lin J. G. and Huang S. J. (1997b) Alkaline and ultrasonic pretreatment of sludge before anaerobic digestion. Water Sci. Technol. 36(11), 155-162.

Chu C. P., Feng W. H., Chang B. V. and Lee D. J. (1999) Reduction in microbial density level through freezing and thawing. Water Res. 33, 3532-3535.

Cousin C. P. and Ganczarczyk J. J. (1998) Effects of salinity on physical characteristics of activated sludge flocs. Water Qual. Res. J. Can. 33, 565.

Dollerer J. and Wilderer P. A. (1993) High pressure treatment of organic wastes. Water Sci. Technol. 28(1), 243-248.

Gaudy Jr. A. F., Yang P. Y. and Obayashi A. W. (1971) Studies on the total oxidation of activated sludge with and without hydrolytic pretreatment. J. Water Pollut. Control Fed. 43, 40-54.

Gorczyca B. and Ganczarczyk J. J. (1998) Structure and porosity of alum coagulated flocs, Unpublished work.
Haug R. T., Stuckey D. C., Gossett J. M. and McCarty P. L. (1978) Effect of thermal pretreatment on digestibility and dewaterability of organic sludge. J. Water Pollut. Control Fed. 50, 73-85.

Higgins M. J. and Novak J. T. (1997a) The effect of cations on the settling and dewatering of activated sludges: laboratory results. Water Environ. Res. 69, 215-224.

Higgins M. J. and Novak J. T. (1997b) Dewatering and settling of activated sludges: the cases for using cation analysis. Water Environ. Res. 69, 224-232.

Hughes D. E. and Stafford D. A. (1976) The microbiology of the activated-sludge processes. Crit. Rev. Environ. Control 7, 233-257.

Jean D. S. and Lee D. J. (1999) Effects of salinity on expression dewatering of waste activated sludge. J. Colloid Intef. Sci. 215, 43-445.

Jepsen S., Krause M. and Gruttner H. (1997) Reduction of fecal streptococcus and salmonella by selected treatment methods for sludge organic waste. Water Sci. Technol. 36(11), 203-210.

Jorand F., Guicherd P., Urbain V., Manem J. and Block J. C. (1994) Hydrophobicity of activated sludge flocs and laboratory-grown bacteria. Water Sci. Technol. 30, 211-218.

Jorand F., Zartarian F., Thomas F., Block J. C., Bottero J. Y., Villemin G., Urbain V. and Manem J. (1995) Chemical and structural (2D) linkage between bacteria within activated sludge flocs. Water Res. 29, $1639-1647$.

Kenzevic Z., Mavinic D. S. and Anderson B. C. (1994) Pilot scale evaluation of anaerobic codigestion of primary and pretreated waste activated sludge. Water Environ. Res. 67, 835-841.

Kiff R. J. and Thompson R. T. (1979) Physical methods for the extraction of bacteria exopolymers from activated ludge biomass. Biotechnol. Lett. 1, 183-186.

King R. O. and Forster C. F. (1990) Effects of sonication on activated sludge. Enzyme Microbiol. Technol. 12, 109-115.

Knapp J. S. and Howell J. A. (1978) Treatment of primary sewage sludge with enzymes. Biotechnol. Bioeng. 20, 1221-1234.

Kopp J., Muller J., Dichtl N. and Schwedes J. (1997) Anaerobic digestion and dewatering characteristics of mechanically excess sludge. Water Sci. Technol. 36(11), 129-136.

Lee D. J. (1994) Floc structure and bound water content in excess activated sludges. J. Chin. I. Chem. Engrs. 25, 201-207.

Lee D. J. (1997) Filter medium clogging in cake filtration. A.I.Ch.E.J. 43, 273-276.

Lee D. J. (1999) Reply to Comment by L. Gmachowski to Hydrodynamic drag force exerted on a moving floc and its implications to free settling test. Water Res. 32, 860-868; Water Res., 33, 1116 (1998).

Lee D. J. and Hsu Y. H. (1995) Measurement of bound water in sludges: a comparative study. Water Environ. Res. 67, 310-317.

Li Y. Y. and Noike T. (1992) Upgrading of anaerobic digestion of waste activated sludge by thermal pretreatment, Water Sci. Technol. 26(3-4), 857-866.

Lin J. G., Rajan R. V. and Ray B. T. (1989) Low-level chemical pretreatment for enhanced sludge solubilization. J. Water Pollut. Control Fed. 61, 1678-1683.

Monnier H., Wilhelm A. M. and Delmas H. (1999) The influence of ultrasound on micromixing in a semi-batch reactor. Chem. Eng. Sci. 54, 2953-2961.

Mukherjee S. R. and Levine A. D. (1992) Chemical solubilization of particulate organics as a pretreatment approach, Water Sci. Tecnhol. 26(9-11), 2289-2292.

Muller J. and Schwedes J. (1996) Dewatering of disintegrated excess sewage sludge, Water Sci. Tecnhol. 26(9-11), 2289-2292. 
Neppiras E. A. (1980) Acoustic cavitation. Phys. Rep. 61, 160-251.

Novak J. T., Love N. G., Smith M. L. and Wheeler E. R. (1998) The effect of cationic salt addition on the settling and dewatering properties of an activated sludge. Water Environ. Res. 70, 984-996.

Pancorbo O. C., Bitton G., Farrah S. R., Gifford G. E. and Overman A. R. (1988) Poliovirus retention in soil column after application of chemical- and polyelectrolyte-conditioned dewatered sludge. Appl. Envir. Microbiol. 54, 118-123.

Prasad D., Henry J. G. and King A. (1993) Coliform inactivation in sludge by copper sulfate. Can. J. Civ. Eng. 20, 814

Qian Z., Sagers R. D. and Pitt W. G. (1997) Effect of ultrasonic frequency upon killing of $P$. aeruuginosa biofilms. Ann. Biomed. Eng. 25(1), 69.

Sanin F. D. and Vesilind P. A. (1996) Synthetic sludge: a physical/chemical model in understanding bioflocculation. Water Environ. Res. 68, 927-933.

Schuh R., Phillipp W. and Strauch D. (1985). Influence of sewage sludge with and without lime treatment on the development of Ascaris suum eggs. In Inactivated of Microorganisms in Sewage Sludge by Stabilization Process, eds. D. Strauch, A. H. Havelaar and P. L'Hermite, pp. 100-112. Elsevier Applied Science Publ, London, UK.

Stuckey D. C. and McCarty P. L. (1978) Thermaochemical pretreatment of nitrogen materials to increase methane yield. Biotechnol. Bioeng. 8, 219-223.
Stuckey D. C. and McCarty P. L. (1984) The effect of thermal pretreatment on the anaerobic biodegradability and toxicity of waste activated sludge. Water Res. 18, 1343-1353.

Tatsuo S., Kudo K. and Nasu Y. (1993) Anaerobic waste activated sludge digestion-a bioconversion mechanism and kinetic model. Biotechnol. Bioeng. 41, 1082-1091.

Tiehm A., Nickel K. and Neis U. (1997) The use of ultrasound to accelerate the anaerobic digestion of sewage sludge. Water Sci. Technol. 36(11), 121-128.

Urban V., Block J. C. and Manem J. (1993) Bioflocculation in activated sludge: an analytic approach. Water Res. 27, 829-838.

Vesilind P. A., Hung W. and Martel C. J. (1991) Agitation and filterability of freeze/thawed sludge. J. Cold Region Eng. ASCE. 5, 77-83.

Wen H. J. and Lee D. J. (1998) Strength of polymer flocculated clay flocs. Adv. Environ. Res. 2, 390-396.

Williams A. R., Forster C. F. and Hughes D. E. (1971) Using an ultrasonic technique in the enumeration of activated sludge bacteria. Effluent Water Treat. J. 11, 83-86.

Williams A. R., Stafford D. A., Callely A. G. and Hughes D. E. (1970) Ultrasonic dispersal of activated sludge flocs. J. Appl. Bacteriol. 33, 656-663.

Woodard S. E. and Wukasch R. F. (1994) A hydrolysis/ thickening/filtration process for the treatment of waste activated sludge. Water Sci. Technol. 30(3), 29-38.

Yasui H. and Shibata M. (1994) An innovative approach to reduce excess sludge production in the activated sludge process. Water Sci. Technol. 30(9), 11-20. 